\title{
Clinical Experience of Thromboembolic Complications of Coil Embolization for Intracranial Aneurysms with Literature Review
}

\author{
Sung-Kyun Hwang $\cdot$ Sung-Hak Kim \\ Department of Neurosurgery, College of Medicine, Ewha Womans University$$
=\text { 국 문 조록 }=
$$ \\ 뇌동맥류의 코일 색전술중에 혈전 합병증의 임상경험 및 문헌 고찰 \\ 이화여자대학교 의과대학 신경외과학교실 \\ 황 승 균·김 성 학
}

목 적 : 저자들은 뇌동맥류의 코일 색전술 치료 중에 발생하는 혈전 합병증을 가진 환자들의 임상결과 를 문헌고찰과 함께 보고하고자 한다.

방 법 : 저자들은 본원에서 2004년 8월부터 2008년 8월까지 160명의 환자에서 176명의 뇌동맥류를 GDC (Guglielmi detachable coils)로 코일 색전술을 시행하였다. 그 중 66명이 남자였으며, 94명이 여자 였다. 환자의 연령은 평균 58.8 세로 22 세부터 82 세까지의 분포를 가지고 있다. 저자들은 이 환자군에 대하여 합병증과 결과를 후행적으로 분석하였다.

결 과 : 시술 중이나 시술 후 오직 6 명 $(3 \%)$ 의 환자에게서 혈전합병증이 발생하였고, 이 현상은 stent 나 catheter에 연관된 합병증과 연관이 있을 것으로 사료된다. 다른 2 명의 환자는 시술 후 경색과 함께 지연성 출혈이 발생하였는데, 이는 시술 중 혹은 시술 후 사용하는 항혈전제와 연관이 있는 것으로 생각 된다. 나머지 2 명의 환자는 시술 중에 혈전합병증이 발생하였으나 동맥내 혈전용해제로 치료되었다.

결 론 : 혈관내수술 중의 혈전합병증을 방지하기 위해서는 표준적인 치료의 한계점과 혈전 예방책에 대 한 새로운 치료방법의 보다 깊은 이해가 필요한 것으로 사료된다.

중심 단어 : Thromboembolism · Intracranial aneurysms · Coil embolization .

\section{Introduction}

The endovascular treatment of an intracranial aneurysm by using Guglielmi detachable coils (GDC) was first introduced by Guglielmi et al in $1991^{9)}$. Since then, GDC treatment has undergone rapid change, and recent advanced techniques make it possible to improve anatomic and clinical outcomes ${ }^{14) 17) 22)}$. Although this treatment has become an accepted alternative to surgery, thromboembolic events still constitute the main complication ${ }^{15) 19)}$.

The development of new materials and advances in vascular catheterization techniques that have made it possible to treat various diseases via an endovascular approach in last decade. With the growing use of endovascular procedures in neurosurgical practice, adequate 
Table 1. Patient with thromboembolic complications

\begin{tabular}{cccccccc}
\hline No & $\begin{array}{c}\text { Age (years) } \\
\text { Sex }\end{array}$ & Site & $\begin{array}{c}\text { Size } \\
(\mathrm{mm})\end{array}$ & $\begin{array}{c}\text { Hunt and Hess } \\
\text { grade at } \\
\text { presentation }\end{array}$ & $\begin{array}{c}\text { Antiplatelet } \\
\text { drug response }\end{array}$ & Comment & GOS \\
\hline 1 & $48 / \mathrm{M}$ & ACOM & $8 \times 3.5$ & 4 & Complete & $\begin{array}{c}\text { Recanaliztion by } \\
\text { intraarterial thrombolysis }\end{array}$ & 2 \\
2 & $50 / \mathrm{F}$ & ICA & $2 \times 3$ & Unnuptured & $\begin{array}{c}\text { Complete } \\
\text { Stent induced thrombosis }\end{array}$ & 5 \\
3 & $45 / \mathrm{F}$ & MCA & $4 \times 5$ & Unnuptured & Partial & $\begin{array}{c}\text { Hemomagic } \\
\text { transformation }\end{array}$ & 5 \\
4 & $44 / F$ & MCA & $6.5 \times 7$ & Unnuptured & Partial & $\begin{array}{c}\text { Hemomagic } \\
\text { transformation }\end{array}$ & 5 \\
5 & $41 / F$ & MCA & $5 \times 7$ & 2 & Complete & $\begin{array}{c}\text { Transient dysphasia } \\
\text { Infarction }\end{array}$ & 5 \\
6 & $65 / M$ & PCOM & $2 \times 4$ & 2 & None & 2 \\
\hline
\end{tabular}
cerebral artery a neurysm, PCOM : posterior communic ating artery aneurysm, GOS: Glasgow outc ome scale

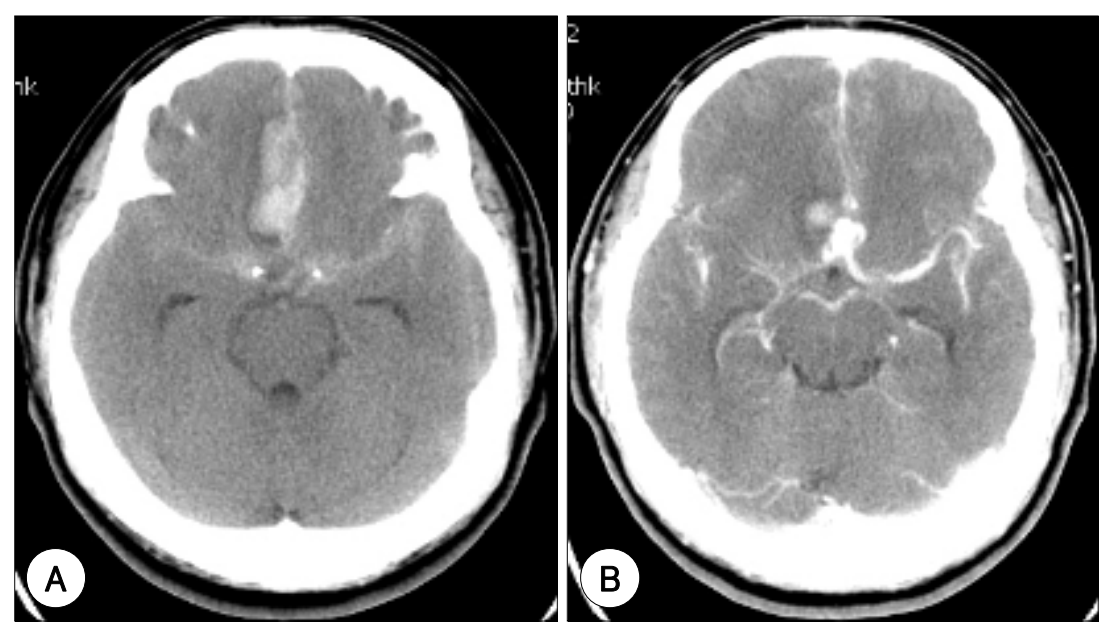

Fig. 1. No. 1 case. A : Computed tomography shows subarachnoid hemomage in basal cistem \& interhemispheric cistem with diffuse brain swelling. B : Enhanced computed tomography shows aneurysmal sac at anterior communic ating artery.

knowledge of basic pathophysiological principales is important.

In this article, we review our thromboembolic complications associated with endovascular procedures, and describe our clinical outcomes with literature review.

\section{Patients and Method}

Between August 2004 and August 2008, we performed endosaccular embolization with GDCs for 160 patients with 176 cerebral aneurysms including ruptured and unruptured aneurysms at our hospital. Sixty-six patients were male and 94 were female. The age of patients ranged from 22 to 82 years (average, 58.8 years). All ruptured aneurysms were treated within 2 weeks. In this study we retrospectively evaluated this group with regard to complications rates and outcome.

The locations of the aneurysms were the internal carotid artery in 23, anterior communicating artery in 36, distal anterior cerebral artery in 8 , anterior choroidal artery in 7 , posterior communicating artery in 43 , middle cerebral artery in 40, basilar tip in 9, vertebral and basilar artery in 10 patients. One hundred sixty-one aneurysms were small (diameter lesser than $10 \mathrm{~mm}$ ), and thirteen were large (diameter $10-25 \mathrm{~mm}$ ), two were giant (diameter more than $25 \mathrm{~mm}$ ). One hundred forty-two aneurysms had small necks (neck diameter $4 \mathrm{~mm}$ ), and thirty four had wide necks (neck diameter $4 \mathrm{~mm}$ ). The method used for such measurements has been published previously ${ }^{24) 8)(9) 13) 14) 20) 22) . ~}$ 


\section{Results}

Patients were included in this category if they had clinical symptoms of cerebral ischemia, either angiographic or clinical, of thromboembolism. Clots were angiographically noted but, if there was no clinical evidence of cerebral ischemia, such events were not recorded as complications. Of 160 patients, only six patients had the thromboembolic complications during or after procedures (3\%, Table 1). Two of them suffered fully recovered transient ischemic attack after procedure, which might be stent and catheter related complication. They did not have a suffered a watershed stroke from hypotension/hypoperfusion during a procedure. Another two patient had a ischemia and delayed hemorrhagic transformation, which were related to use of antiplatelet drug during or after procedures. The other two patients had thromboem- bolic complications during procedure which were relieved by intraarterial fibrinolytic management. None of patients died of these thromboembolic complications.

\section{Discussion}

Thromboembolic complications are reported in 5-10\% of patients treated endovascularly ${ }^{2) 11(13) 15) 16) 22)}$, though permanent deficit is less frequent, with rates of $1-5 \%{ }^{4(6) 8)}$. Associations between the development of thrombosis, the size of the catheter/introducer, and the duration of the procedure have been established. Thromboembolic complications of coiling are most commonly recognized as distal emboli ${ }^{4) 15)}$ on check angiography and less commonly occur with a filling defect at the coil-ball/parentartery junction ${ }^{21)}$. However, we had an increased prevalence of local thrombosis. Large aneurysm diameter and coil protrusion are independent risk factors for post-

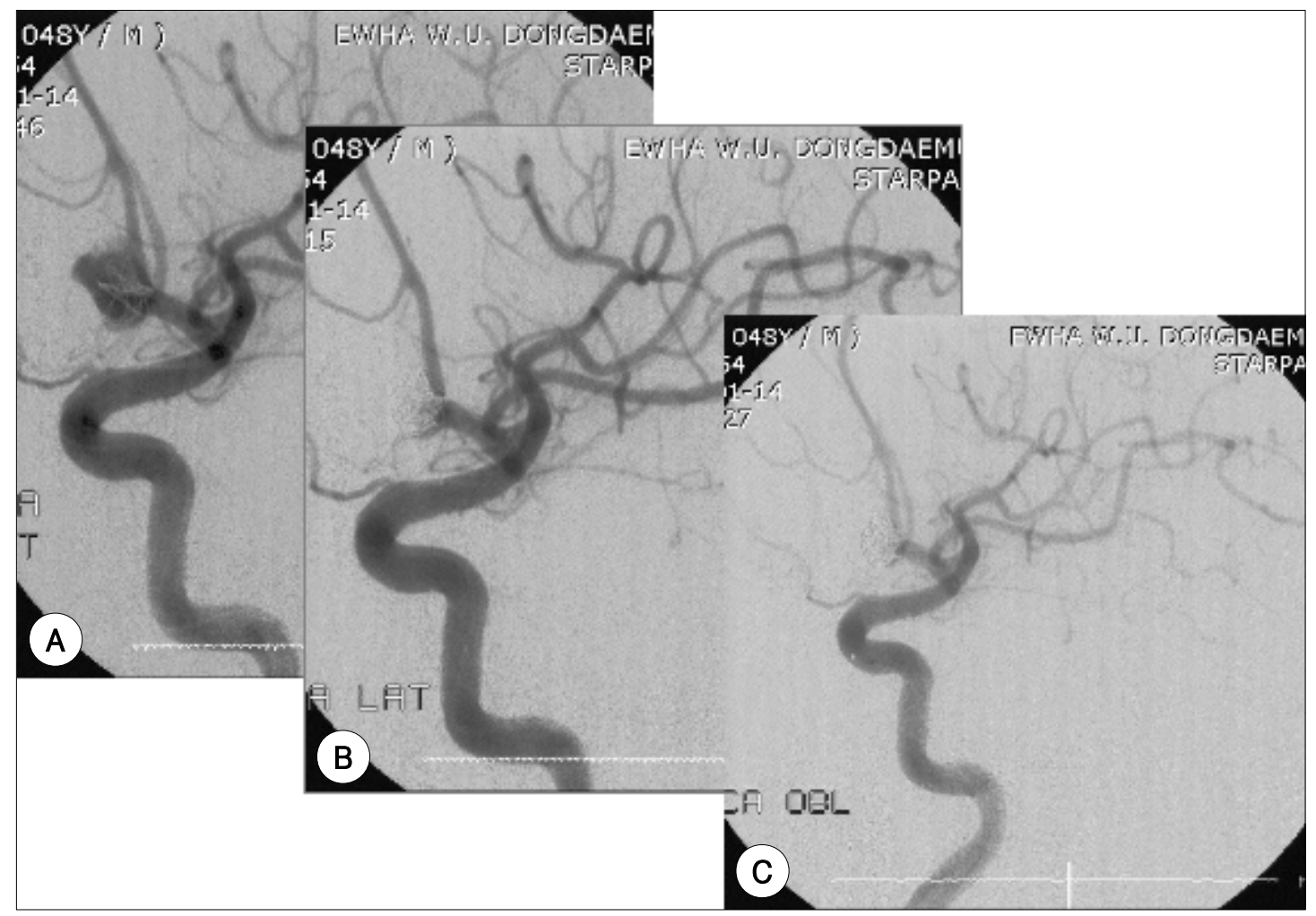

Fig. 2. No. 1 case. A : Digital subtraction angiograpy shows saccular aneurysmal sac at anterior communicating artery aneurysm, which is embolized with detachable coils. B, C : During coil embolization, thromboembolic clot occlude ipsilateral anterior cerebral artery(A2). By thrombolysis with urokinase (200,000 unit) and Reopro (10mg), occluded artery is suc cessfully rec ana lized. 

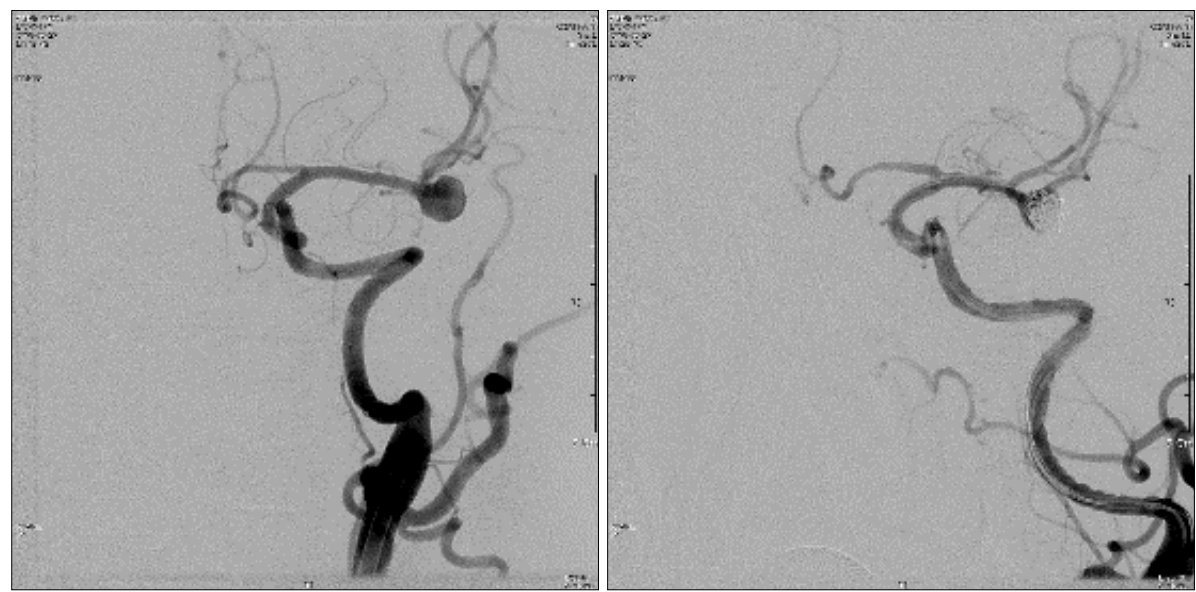

Fig. 3. No. 5 case. Digital subtraction angiograpy shows saccular aneurysmal sac at middle cerebral artery aneurysm, which is embolized with detachable coils.

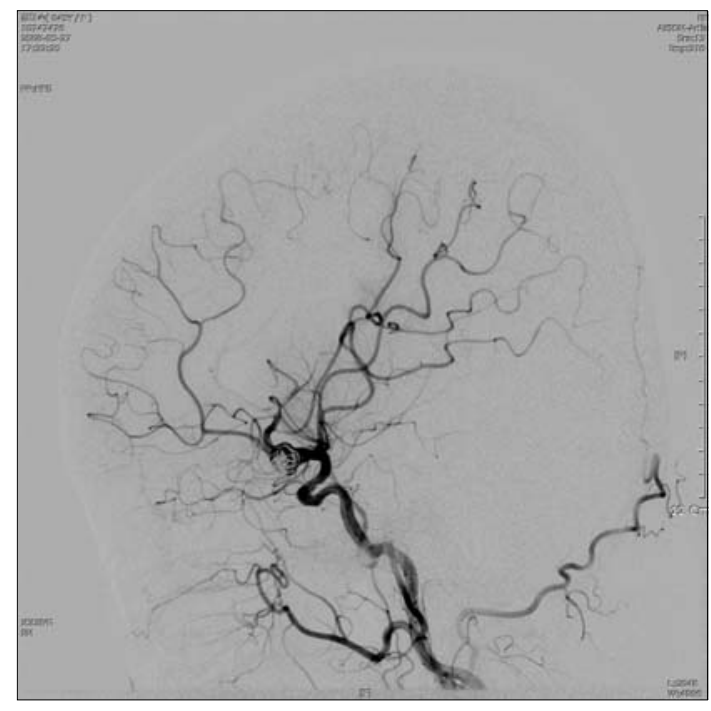

Fig. 4. No. 5 case. After embolization for aneurysm, digital subtraction angiograpy shows that middle cerebral artery (M2, M3) is not visualized by thromboembolic clot. This patient suffered a transient dysphasia after procedure, but discharged with no neurological defic it.

procedural thromboembolic events ${ }^{6}$. Stroke, usually from thrombus in the parent vessel with downstream embolization, remains a significant problem. The actuarial risk of stroke associated with aneurysm coiling has been found by one group, in a retrospective study that only looked at good-grade patients, to equal $3.8 \%{ }^{610)}$. In addition to clinically recognizable clots and strokes, silent infarcts are often detected on postprocedure diffusion-weighted magnetic resonance imaging. There is evidence that these events are quite common ${ }^{12) 18) 20)}$. The outcome of the International Subarachnoid Aneurysm Trial was encouraging to neuroendovascular enthusiasts. There is, unfortunately, no prospectively obtained published data on neuroendovascular technical problems. It is important that endovascular specialists share their poor outcome data, not only to educate their colleagues on the pitfalls of endovascular treatment, but to also improve the level of care.

There are many possible sources for embolic events during GDC treatment of cerebral aneurysms, including friable plaques and iatrogenic dissection in the parent vessels, air bubbles, and thrombus or fresh clots within aneurysms and catheters ${ }^{118)}$. On the other hand, the location of the lesion depends on both the flow patterns in the patient's brain and other unresolved factors. The brain border zone is a favored destination for microemboli because this area has an inadequate blood supply, and once the blood supply is disturbed by microemboli, this area might fall to infarction ${ }^{19}$. Thromboembolic complications can be initially silent, becoming symptomatic only when the infarct enlarges.

Treatment of thrombus formation may be local (mechanical clot extraction and/or disruption) ${ }^{5) 23)}$, and abciximab $^{23)}$, or a combination. Treatment of thrombotic complications in ruptured aneurysms requires a fine balance between maintaining intra-aneurysmal occlusion(to which coil packing and thrombosis contribute) ${ }^{3)}$ and lysis of the thrombus in the parent artery. Its action is 
prolonged and, though reduced, it may persist as long as a week after administration. In contrast to heparin, abciximab is not easily reversed. Despite these theoretic effects, abciximab has been used for carotid and vertebrobasilar rescue and for the treatment of acute stroke, without a substantial increase in intracerebral hemorrhage. Therefore, abciximab does not appear to have intracranial risk on par with that of thrombolytic agents. this was observed at the time of diagnostic angiography immediately before emergency coiling. Abciximab immediately cleared the soft basilar thrombus, but the focal thrombus persisted at the origin of the superior cerebellar artery. This clot did not respond to attempted mechanical disruption by using the guidewire, leading us to conclude that this was hard, atheroembolic material dislodged from the vertebral artery dissection. We suggest that an infusion may potentially confer an additional and unnecessary risk of hemorrhage. Postprocedural anticoagulation can be effectively maintained with heparin followed by aspirin and/or clopidogrel. Technical complications associated with the use of GDCs include aneurysmal perforation and rupture, parent artery occlusion, cerebral embolism, coil migration, vasospasm, and hemodynamic ischemia with inadequate collateral reserve. The largest contributor to complications of GDC treatments is iatrogenic brain ischemia caused by thromboembolic events ${ }^{714) 19}$. This may be caused by thrombus form athrombosis in the aneurysm sac, or from herniation of the coils into the parent vessel. Although clinical thromboembolic complications have been reported to occur in a range of $1.0 \%$ to $28 \%$, the complications in these studies were defined as new focal deficits, a change in mental status, or abnormalities at postprocedural computed tomography or conventional magnetic resonance imaging $^{914)}$. Rordorf et al ${ }^{18)}$ suggested that thromboembolic events related to GDC techniques may be more common than what has been reported ; in fact, silent embolism occurred in $61 \%$ of the 14 cases in their study. GDC treatment is effective with an acceptable morbidity rate for small aneurysms with a small neck owing to the high initial success rate and low mortality and morbidity rates $^{914)}$. In wide-neck and large aneurysms, however, the combined use of the balloon-assisted technique enables a denser packing of aneurysms and markedly im- proves the anatomic results after the treatment. Some authors report that the occurrence of thromboembolic events with the use of the balloon-assisted technique is not different from that of the conventional GDC technique. However, this technique requires sophisticated handling, frequent use of guidewires and microcatheters, the need for temporary occlusion of the parent vessel, and repeated inflation and deflation of the balloon. Use of the balloon-assisted technique is theoretically a risk factor for thromboembolic complications, because the risk of significant emboli will likely increase with increasing procedural complexity, potential sites for the generation of microemboli increase, and longer procedure time. On the other hand, the process of intra-aneurysmal clot organization in large aneurysms is delayed and incomplete, and it may cause delayed postprocedure ischemic events. Derdeyn et $\mathrm{al}^{6)}$ reported that larger aneurysm diameter and protruding loops of coils are risk factors for postprocedure ischemic events after GDC treatment. The current results show that the occurrence of thromboembolic events depended on the procedural complexity, such as larger aneurysms and the use of balloon-assisted techniques. Therefore, in the case of wide-neck or large aneurysms, we have to balance the risk of thromboembolic events and the better anatomic outcome associated with the balloon-assisted technique.

Bendszus et $\mathrm{al}^{1)}$ reported that a silent embolism related to diagnostic angiography occurred in $26 \%$ of their cases. Their embolic lesions were located in the distal vascular territory of small cortical, subcortical, or perforating vessels. Whenever possible, clot disruption by fragmentation is carried out before and in combination with chemical thrombolysis ; clot fragmentation alone is never used as the sole solution. The purpose of fragmentation is twofold : to establish flow beyond the thrombus, permitting passage of the fibrinolytic drug, the heparin, and the intrinsic fibrinolytic factors into the occluded area, and to increase the surface of the clot accessible to the drug. The results of combination of clot fragmentation and fibrinolysis suggest that fragmentation and superselective drug infusion may improve the rate of recanalization. The rate of recanalization indicates that the early administration of a fibrinolytic drug increases the chances of favorable clot dissolution. Spontaneous thrombolysis 
has been estimated to be $20 \%$ during the first 24 hours and $80 \%$ within the first week after ictus.

We believe that fibrin or thrombus formation was induced at the tip of the catheter or around the coil. However, on some occasions, the occlusive material may have been an embolus from a preexisting thrombosis within the aneurysmal sac that was dislodged during coil maneuvering. These emboli originate from thrombotic material a long time before anticoagulant therapy is given, resulting in clots with different characteristics. Another factor that must be considered is the different vulnerability to ischemia found in different regions of the brain. In our opinion, the risks of clotting do not correlate with the size of the aneurysm but rather with its location and with the extent of experience of the doctor in charge.

Most thromboemboli in our series occurred in the middle cerebral artery territory, which was also the most frequent location of the aneurysms. Thrombosis is more likely in cases in which coils protrude from the aneurysm into the lumen of the main artery. Complications related to fibrinolytic therapy were seen in three patients. Two suffered aneurysmal rebleeding, in both instances the patients underwent embolization during the acute phase of an subarachnoid hemorrhage.

\section{Conclusion}

In endovascular procedures, arterial injury, and the use of catheter, contrast agents, and implanted devices with thrombogenic potential place patients at risk for thrombosis and embolization. Extensive research has been performed to elucidate the pathophysiological features underlying thrombosis associated with endovascular procedures.

Although permanent clinical sequelae are rare, the high rate of thromboembolic events suggests that alternations in the technique, such as the addition of antiplatelet agents and development of new embolic materials that could be packed by means of simple methods, should be considered. Experience, attention to procedural details, proper patient selection, and measures to reduce the rate of symptomatic and silent embolisms may permit safer aneurysm treatment in the future.

\section{References}

1) Bendszus M, Koltzenburg M, Burger R, Warmuth-Matz M, Hofmann E, Solymosi L : Silent embolism in diagnostic cerebral angiography an neurointerventional procedures : a prospective study. Lancet 1999 ; 354 : 1594-1597

2) Brilstra EH, Rinkel GJE, van der Graf Y, van Rooij WJJ, Algra A : Treatment of intracranial aneurysms with embolization with coils : a systematic review. Stroke $1999 ; 30: 470-476$

3) Byrne JV, Hope JKA, Hubbard N, Morris JH : The nature of thrombus induced by platinum and tungsten coils in saccular aneurysms. Am J Neuroradiol 1997 ; $18: 29-33$

4) Cognard C, Weill A, Castaings L, Rey A, Moret J : Intracranial berry aneurysms : angiographic and clinical results after endovascular treatment. Radiology 1998 ; $206: 499-510$

5) Cronqvist M, Pierot L, Boulin C, Cognard C, Costains L, Moret J : Local intraarterial fibrinolysis of thromboemboli occurring during endovascular treatment of intracerebral aneurysm : a comparison of anatomic results and clinical outcome. Am J Neuroradiol 1998 ; $19: 157-165$

6) Derdeyn CP, Cross III DT, Moran CJ, Brown GW, Pilgram TK, Diringer HN, et al. : Postprocedure ischemic events after treatment of intracranial aneurysms with Guglielmi detachable coils. J Neurosurg 2002 ; 96 : 837-843

7) Debrun GM, Vinuela FV, Fox AJ : Aspirin and systemic heparinization in diagnostic and interventional neuroradiology. Am J Neuroradiol 1982 ; 3 :337-340

8) Eskridge JM, Song JK : Endovascular embolization of 150 basilar tip aneurysms with Guglielmi detachable coils : results of the Food and Drug Multicenter Clinical trial. J Neurosurg $1998 ; 89$ :81-86

9) Guglielmi G, Vinuela F, Dion J, Duckwiler G : Electrothrombosis of saccular aneurysms via endovascular approach. part 2 : prelieminary clinical experience. $J$ Neurosurg $2004 ; 25: 1058-1061$

10) Henkes H, Fischer S, Weber W, Miloslavski E, Felber S, Brew S, et al. : Endovascular coil occlusion of 1811 intracranial aneurysms : early angiographic and clinical results. Neurosurgery 2004 ; 54 :268- 285

11) Horowitz M, Samson D, Purdy P : Does electrothrom- 
bosis occur immediately after embolization of an aneurysm with Guglielmi detachable coils? Am J Neuroradiol $1996 ; 18: 510-513$

12) Klotzsch C, Nahser HC, Henkes H, Kuhne D, Berlit $\mathrm{P}:$ Detection of microemboli distal to cerebral aneurysms before and after therapeutic embolization. Am J Neuroradiol $1998 ; 19: 1315-1318$

13) Mcdougall CG, Halbach VV, Dowd CF, Higashida RT, Larsen DW, Hieshima GB : Endovascular treatment of basilar tip aneurysms using electrolytically detachable coils. J Nerosurg 1996 ; 84 :393-399

14) Murayama Y, Vinuela F, Duckwiler GR, Gobin YP, Guglielmi G : Embolizatiion of incidental cerebral aneurysms by using the Guglielmi detachable coil system. J Neurosurg $1999 ; 90: 207-214$

15) Pelz DM, Lownie SP, Fox AJ : Thromboembolic events associated with treatment of cerebral aneurysms with Guglielmi detachable coils. Am J Neuroradiol 1998 ; $19: 1541-1547$

16) Pruvo JP, Leclerc $X$, Ares GS, Lejeune JP, Leys D : Endovascular treatment of ruptured intracranial aneurysms. J Neurol 1999 ; 246 :244-249

17) Qureshi AI, Suri MF, Khan J, Kim SH, Fessler RD, Ringe AJ, et al : Endovascular treatment of intracranial aneurysms by using Guglielmi detachable coils in awake patients : safety and feasibility. J Neurosurg 2001 ; 94 : 880-885

18) Rordorf G, Bellon RJ, Budzik RF, Budzik RE, Fiarkas J, Reinking GR, Pergolizzi RS, et al : Silent thromboe- moblic events associated with the treatment of unruptured cerebral aneurysms by use of Guglielmi detachable coils : prospective study applying diffusionweighted imaging. Am J Neuroradiol $2001 ; 22: 5-10$

19) Sakai H, Sakai N, Higashi T, Higashi $T$, Iihara $K$, Takahashi J, Kogure S, et al : Embolic complications of endovascular surgery for cerebrovascular diseases : evaluation with diffusion-weighted MR imaging. Intervent Neuroradiol 2000 ; 6 (Suppl) :223-226

20) Soeda A, Sakai N, Sakai H, Sakai H, Muraok, Ihara K, Yamada AL, et al : Thromboembolic events associated with Guglielmi detachable coil embolization of asymptomatic cerebral aneurysms : evaluation of 66 consecutive cases with use of diffusionweighted MR imaging. Am J Neuroradiol 2003 ; 24 : 127- 132

21) Song JK, Niimi Y, Fernandez PM : Thrombus formation during intracranial aneurysm coil placement : treatment with intraarterial abciximab. Am J Neuroradiol $2004 ; 25: 1147-1153$

22) Vinuela F, Duckwiler G, Mawad M : Guglielmi detachable coil embolization of acute intracranial aneurysm : perioperative anatomical and clinical outcome in 403 patients. J Neurosurg 1997 ; 86 : 475-482

23) Workman MJ, Cloft HJ, Tong FC, Tong FC, Dion JE, Jensen ME, Marx WR, et al : Thrombus formation at the neck of cerebral aneurysms during treatment with Guglielmi detachable coils. Am J Neuroradiol 2002 ; 23 : 1568-1576 